https://doi.org/10.17816/MAJ191S129-30

\title{
THE EFFECT OF GLUTAMATE ON THE MIGRATION OF T CELLS FROM HEALTHY DONORS AND PATIENTS WITH MULTIPLE SCLEROSIS IN VITRO
}

\author{
M.A. Maksimova ${ }^{1}$, U.Sh. Kuzmina ${ }^{1}$, K.Z. Bakhtiyarova ${ }^{2}$, Yu.V. Vakhitova ${ }^{1}$ \\ ${ }^{1}$ IBG UFRC RAS, Ufa, Russia; \\ ${ }^{2}$ FSBEI HE BSMU MOH, Ufa, Russia

\section{ВЛИЯНИЕ ГЛУТАМАТА НА МИГРАЦИЮ Т-КЛЕТОК ЗДОРОВЫХ ДОНОРОВ И БОЛЬНЫХ РАССЕЯННЫМ СКЛЕРОЗОМ В МОДЕЛИ IN VITRO}

\author{
М.А. Максимова ${ }^{1}$, У.Ш. Кузьмина ${ }^{1}$, К.З. Бахтиярова ${ }^{2}$, Ю.В. Вахитова ${ }^{1}$ \\ ${ }^{1}$ ФГБУН «Институт биохимии и генетики» Уфимского научного центра РАН, Уфа; \\ ${ }^{2}$ ФГБОУ ВО «Башкирский государственный медицинский университет» Минздрава РФ, Уфа
}

\begin{abstract}
Aim of study. To study chemotactic properties of glutamate and glutamate receptor agonists on $\mathrm{T}$ cells migration from healthy donors and patients with multiple sclerosis (MS) in vitro. Materials and methods. T cell migration of 15 patients with MS and 15 healthy donors was studied in vitro using transwells. Lymphocytes were activated with PMA $(10 \mathrm{ng} / \mathrm{mL})$. T cells were added to transwells with fibronectin $(10 \mu \mathrm{g} / \mathrm{mL})$ pretreated membrane. The lower chamber contained glutamate or AMPA or NMDA (100 $\mu \mathrm{M}$ for each) in complete RPMI medium. Migrated cells were collected and stained with antibodies to CD3-marker for subsequent analysis by cytofluorimetry. Results and conclusion. In presence of glutamate, there is a tendency to a decrease in migration activity in both groups of donors. T-cell chemotaxis of healthy donors, but not MS patients, decreased in concentration gradient of NMDA. The activation of lymphocytes with PMA leads to a decrease in the number of migrated cells by an average of $17 \%(p<0.01)$. In MS patients there is a tendency to an increase in chemotaxis of activated cells in concentration gradient of glutamate, and a decrease with AMPA. Thus, glutamate and glutamate receptors agonists do not possess pronounced chemotactic properties, but rather enhance T-cell migration through synthesis of adhesion molecules on the surface of lymphocytes and endothelium.
\end{abstract}

Keywords: migration; T-cells; glutamate; multiple sclerosis.

Цель исследования. Изучить хемотактические свойства глутамата и агонистов его рецепторов на миграцию Т-клеток здоровых доноров и больных рассеянным склерозом (РС) в модели in vitro. Материалы и методы. Миграцию Т-клеток 15 больных РС и 15 здоровых доноров изучали в модели in vitro с использованием трансвеллов. Лимфоциты активировали с РМА (10 нг/мл). Т-клетки добавляли в трансвеллы, мембрана которых обработана фибронектином (10 мкг/мл). В нижней камере содержались глутамат, AMPA или NMDA (100 мкM для каждого) в полной среде RPMI. Мигрировавшие клетки собирали, окрашивали антителами к CD3-маркеру для последующего анализа методом цитофлуориметрии. Результаты и заклюиение. На фоне глутамата наблюдается тенденция к снижению миграционной активности в обеих группах доноров. В градиенте концентраций NMDA наблюдается снижение хемотаксиса T-клеток здоровых доноров, но не больных РС. Активация лимфоцитов с РМА приводит к снижению количества мигрировавших клеток в среднем на $17 \%(p<0.01)$. У больных РС наблюдается тенденция к повышению хемотаксиса активированных клеток в градиенте глутамата, а под действием АМРА - к снижению. Таким образом, глутамат и агонисты его рецепторов не обладают выраженными хемотактическими свойствами но, вероятно, усиливают миграцию Т-клеток посредством синтеза молекул адгезии на поверхности лимфоцитов и эндотелия.

Ключевые слова: миграция; Т-клетки; глутамат; рассеянный склероз.

Introduction. The primary excitatory neurotransmitter of the nervous system, glutamate, was also observed in cells of the immune system. T cells express functional glutamate receptors and secrete glutamate, affecting neighboring cells. Glutamate is able to activate lymphocytes inducing their key functions. Migration of autoreactive T lymphocytes from blood vessels to the central nervous system is an important step in the pathogenesis of multiple sclerosis (MS). According to the literature, elevated glutamate levels affect $T$ cells, which penetrate across blood brain barrier, leading to destruction of neuronal myelin sheath in MS [1]. The process of cell migration mediated by glutamate is controlled by many factors, which are not fully understood.

Materials and methods. PBMCs were purified from blood of 15 patients with relapsing-remitting MS in relapse phase and 15 healthy donors by den- 
sity gradient centrifugation of ficoll. T cell migration was studied in vitro using transwells. Resting or activated by phorbol myristate acetate (PMA, $10 \mathrm{ng} / \mathrm{mL})$ PBMCs $\left(2 \cdot 10^{5}\right.$ cells per sample $)$ were loaded in transwells with fibronectin-coated $(10 \mu \mathrm{g} / \mathrm{mL})$ membrane. Low chamber contained either glutamate, AMPA or NMDA $(100 \mu \mathrm{M}$ for each) in complete RPMI medium. After migration assay cells were collected, incubated with monoclonal antibodies against CD3 marker and labeled with secondary antibodies Alexa Fluor 488. Cell migration was determined by flow cytometry while analyzing the number of events per 1 minute.

Results and discussion. The number of $\mathrm{CD}^{+}$cells in healthy donors and MS patients was consistent and did not change during 2 hours incubation with agonists of glutamate receptors. In presence of glutamate there was a tendency to inhibition of resting $\mathrm{T}$ cells migration activity in both groups of donors. NMDA causes a $25 \%$ decrease in T-cell chemotaxis of healthy donors, but not MS patients. Upon PMA activation of
T-lymphocytes a reduction in number of migrated cells by $17 \%(p<0.01)$ was observed in both groups of donors. In presence of glutamate there is a tendency to an increase of PMA-stimulated $T$ cells chemotaxis in MS patients, and to a decrease with AMPA, when compared with the control group. Activated T-lymphocytes from healthy donors migrated more readily toward the AMPA and NMDA. Thus, we conclude that glutamate and selective agonists of its receptors do not possess noticeable chemoattractant effect. Moreover, there is a tendency to a decrease in the intensity of T-lymphocyte migration in the gradient of their concentration, both at rest and activation. This effect was observed with all studied ligands in MS patients. It should be noted that cell migration might be associated not only with chemoattractant properties of receptor ligands (directed migration) but also with an increase in motility and adhesive properties of cells (non-directional migration), which is probably observed in relation to glutamate and T-lymphocytes.

Table

The effect of glutamate receptor agonists on T cell migration in healthy donors and MS patients in vitro

\begin{tabular}{|l|c|c|c|c|}
\hline \multirow{2}{*}{} & \multicolumn{2}{|c|}{ Healthy } & \multicolumn{2}{c|}{ MS } \\
\cline { 2 - 5 } & Rest & PMA & $66.79 \pm 11.55$ & $44.24 \pm 22.19$ \\
\hline Control & $59.15 \pm 10.57$ & $43.98 \pm 17.36$ & $49.36 \pm 11.82$ & $50.27 \pm 9.80$ \\
\hline Glutamate & $54.15 \pm 4.78$ & $45.44 \pm 14.84$ & $59.27 \pm 19.13$ & $38.73 \pm 8.12$ \\
\hline AMPA & $55.51 \pm 5.24$ & $49.48 \pm 13.69$ & $60.46 \pm 13.23$ & $46.48 \pm 9.62$ \\
\hline NMDA & $44.59 \pm 20.63$ & $53.86 \pm 11.05$ & & \\
\hline
\end{tabular}

Note. The data is presented as the mean \pm standard deviation.

\section{References}

1. Levite M. Glutamate, T cells and multiple sclerosis. J. Neural Transm. (Vienna). 2017;124:775-798. 